\title{
Probe in the Type and Operation of Online Hotel Distribution Channels
}

\author{
Yi Xiaoli ${ }^{1,2}$ \\ ${ }^{1}$ Shenzhen Tourism College of Jinan University, Shenzhen 518053,Guangdong, China \\ ${ }^{2}$ Experimental Teaching Center,Jinan University,Guangzhou510632,Guangdong, China
}

\begin{abstract}
:
By synthesizing the relevant online resources, we find that the hotel online distribution channels can be categorized into four types according to the combination of four groups: hotel group, individual hotel, tourist, online travel agent. Meanwhile, the operation of online channels is mainly depending on the stable contract,unstable contract, membership, evaluation.Its application can be divided into business and non-business usage combining with internet and intranet.
\end{abstract}

Keywords: Hotel, Online distribution channels, Type, Operation, Application

\section{Introduction}

At present, there are a lot of websites about online hotel distribution channels. There are three perplexed questions needed to be answered:What are the various types of websites or online channels that sell hotel rooms? How do these channels make money? Why do hotels use them? Meanwhile, four aspects need to be considered: hotel group, individual hotel,tourist,online travel agent. They all have their own perspectives.

\section{Literature review}

Based on Delphi study from the expert and industry perspectives, channels (and channel participants) are merging, bypassing one another, while simultaneously cooperating and competing with each other. ${ }^{[1]}$ By analyzing different functions of distribution from the visitors' perspective, the providers need to carefully consider the nature of their own product or service,markets, and broader destination characteristics and must decide an appropriate distribution mix. ${ }^{[2]}$

In general, the greater the number of intermediaries, the greater the transaction cost and processing fees; In many cases, luxury hotels in particular tend to offer their highest rates over direct channels-and (ironically) their cheapest rates over the most expensive online intermediaries. ${ }^{[3]}$ Depending on the systems involved in processing bookings, the cost of booking through internet channels can vary considerably;Each system involved in distribution has a different cost to hotels. ${ }^{[4]}$ To counteract intermediaries' attempts to control distribution channels, hotel chains are enhancing and promoting their own websites, and shifting transactions to their own distribution channels. ${ }^{[5]}$

Hoteliers should focus investment on promotion in order to enhance their web- 
sites'effectiveness; The return on hotel website investments should be expected to be in the long run. ${ }^{[6]}$ By the application of hotel best available rate (BAR) pricing, we find that a non-blended rate presentation format does lead to higher willingness to book ratings than a blended rate presentation format. ${ }^{[7]}$

Overall,users had more favorable attitudes and higher intentions to revisit third-party websites than hotel-owned websites. ${ }^{[8]}$ The profiles of different segments of online users were determined by the characteristics of their demographic information;online browsers and purchasers have different expecta-tions for hotel websites. ${ }^{[9]}$ Consumers tend to rely on easy-to-process information, when evaluating a hotel based upon reviews; Higher levels of trust are evident when positively framed reviews focused on interpersonal service. ${ }^{[10]}$

In a word, there are three different things we should pay attention to: different distribution channels have a different cost to hotels; different rate (nonblended or blended rate) does lead to different willingness to book; different segments of online users were determined by the characteristics of their demographic information.Furthermore,positive reviews are worth trusting or encouraging.

\section{Theoretical basis}

Four major online marketing domains are:business-to-consumer,business-to-bu siness,consumer-to-consumer, and consumer-to-consumer;Smart marketers are employing integrated multichannel strategies that use the web to drive sales. ${ }^{[11] 509-}$ ${ }_{512}$ Web sites vary greatly in purpose and content;Online social net-works or web communities give consumers online places to congregate,socialize,exchange views and information. ${ }^{[11] 515}$

The power of internet has revolutio nized how we get together to exchange products,services,and money. ${ }^{[12] 75}$ The purpose of distribution channels is to bring clients and providers together so that they can communicate the information necessary for making a purchase decision and then execute the process of the purchase;There are direct and indirect channels of distribution. ${ }^{[12] 410-411}$

All reservations are made in real time and update the rooms inventory the moment the reservation is confirmed. [13]166 Paid searches can be costly; Hotels pay both for keyword placement and for each customer click on the search engine to the hotel's website. ${ }^{[13] 176}$ Third-party travel sites contract with the hotel a set number of rooms at a deeply discounted rate and then resell those rooms online at websites known for giving consumers the best rate. ${ }^{[13] 181}$ Each third-party travel site had its own proprietary rules, for example: the hotel could not advertise its rooms at a rate lower than the rate on the travel website through any channel of distribution. ${ }^{[13] 182}$

Group business has three positive characteristics appealing to the hotel industry:1) the market is large; 2) groups provide economies of scale;3) group delegates spend more dollars than individual travelers. ${ }^{[13] 224-225}$ Independent hotels or small chains that join a private reservation service generally experience a number of money-saving benefits,such as:save in software,operating and training costs. ${ }^{[13] 183}$ Electronic access into each hotel's property management system allowed chains to perform research \& corporate-wide developments,such as: revenue management, guest history. ${ }^{[13] 166}$

In short, we should drive sales and provide service through a direct or indirect channels, while taking external and internal management into consideration, in order to achieve mutual benefits in the short term and long run. 


\section{The types of online hotel distribution channels}

As shown in Figure 1, the hotel group or hotel chain mainly involves about the hotel with or above medium size. Individual hotel involves mainly about the hotel with small size. Meanwhile, whether it is a wholesaler or retailer, both of them are intermediary agency.

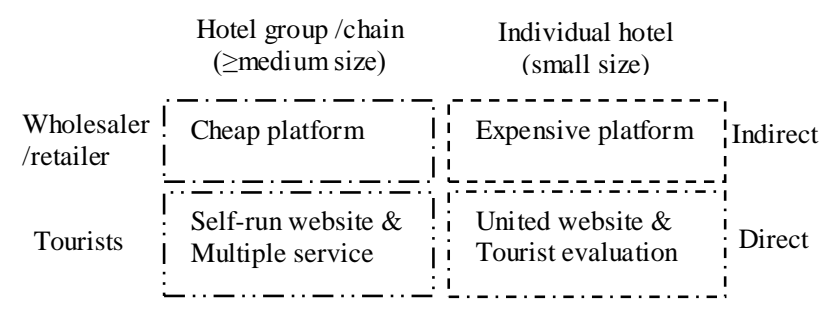

Figure 1 The Types of online

\subsection{Cheap platform}

When the hotel group or hotel chain combines with a online wholesaler or a retailer,due to approximately equal power or capability, it will result in a cheap platform which will give benefits to both sides.For example,Amadeus Hotel Platform,whose Headquarters is in France, gives hotel chains the tools to transform their global operations, global expansion, guests' experience, and proposition to hotel owners. ${ }^{[14]}$ The different hotel groups or chains will share the information and resource from the hotel platform,which can economize costs and give them the economies of scale.

\subsection{Expensive platform}

When the individual hotel combines with a online wholesaler or a retailer, it will result in an expensive platform which will most benefit one side---the online wholesaler or retailer.In this situation, the individual hotel does not have huge resource or capability to negotiate with the online wholesaler or retailer. In most cases, they have to accept the unpleasant clauses or discounts. For example, C-trip, whose Headquarters is in china, claims that it is the biggest online travel agency in China,and its network covers every city; It can guarant ee the lowest prices on domestic hotels. ${ }^{[15]}$ Generally speaking, the lowest price can only come from and depend on the lowest discount or cost.

\subsection{Self-run website}

When the hotel group or hotel chain combines with the tourists, it will come into being self-run website with multiple service. In order to attract \& trace the tourists and control the prices of different rooms, the hotel group or hotel chain always establish their own website. For example, the Hilton hotel group, whose Headquarters is in USA, helps make traveling easier with smart design, innovative restaurant, authentic hospitality and commitment to the global community. ${ }^{[16]}$ What is more, the hotel group or chain often use their own website to introduce their legend history and new activities or discounts, even new hotels.

\subsection{United website}

When the individual hotel combines with the tourists, it will try to join or form a united website. Hardly will anyone trust a hotel without any alliance background in that they do not make sure how long this hotel will last and where they can complain in case of meeting some troubles.So the individual hotel would rather join a united website than set up a website by its own.For example, Hostelworld,whose Headquarters is in Ireland,becomes the fastest-growing online provider with innovative technology and inspire independently minded travelers everywhere; the tourists can know different hostels'overall rating and detailed rating,such as: character, security, location,staff,atmosphere,cleanliness beffore booking a hostel. ${ }^{[17]}$ The individual hotel that makes tremendous efforts will get great rewards and supports from the tourists depending on their evaluation. 


\section{The operation of online hotel distribution channels}

In order to exploit the major operation of online channels, we should keep in our mind:1)The costs of establishing and maintaining a web site vary considerably, depending on the site-owner's commitment and objectives. ${ }^{[18]}$ 2) It is most beneficial for hotels to book reservations through the least-expensive channels, if there is sufficient demand via those channels. ${ }^{[4]}$ 3)No method is consistently cheapest across any of the star ratings; The indirect methods have a great pricing variation than direct methods. ${ }^{[19]}$

Meanwhile, there are two kinds of hotel rates:transparency and nontransparency. They have quite different operation ways: 1) Rate transparency is preferred , if it reduces uncertainty or simplifies the decision process, or if the price was the same and savings became the salient feature; 2) Nontransparent pricing is more effective, if savings are not shown or the price is higher than the alternative. ${ }^{[20]}$ The hotels should understand and use skillfully transparent or non-transparent rate according to its practical situation.

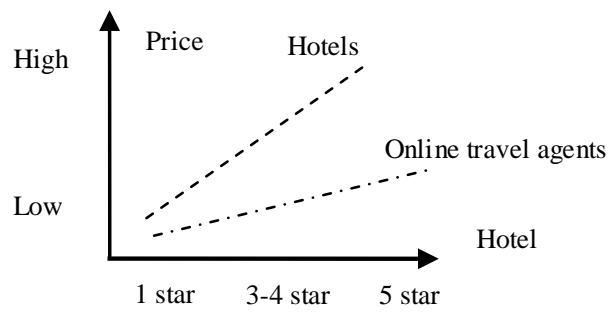

Figure 2 Price variation with hotel class

The price difference between online travel agents and individual service providers(hotels) increased as hotel class increased from one to three stars to four or more stars, with the prices for individual service providers being higher. ${ }^{[21]}$ In order to illustrate this status more explicitly, we draw a figure in Figure 2: The higher the class of the hotel is, the larger the price discrepancy between the hotels and online travel agents will be. Online travel agents will always have a relatively lower price.

As shown in Figure 3, after a deliberate negotiation, the huge hotel group or chain is willing to sign a stable contract with a large wholesaler or retailer based on relatively fair strength from both sides. The contract between the wholesaler or retailer and individual hotel with small size will often be fickle and everchanging. The reason could be various, such as: the requirements of service quality, room rate discounts, etc. The hotel group or chain prefers to attract and keep the tourists by the self membership with annual credits or permanent credits in that self membership can easily be archived, traced and utilized.To the individual hotel, the tourists' evaluation is first and foremost: the higher the evaluation is, the more the tourists would come.

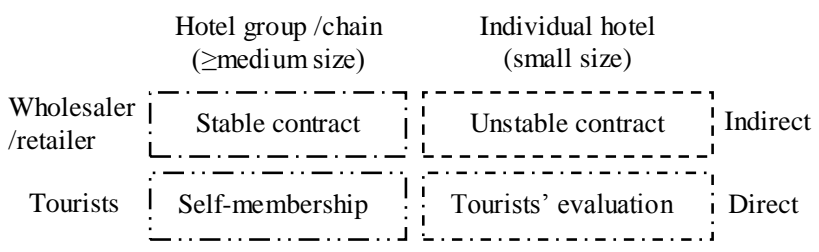

Figure3 The operation of online Channels

Furthermore, indirect channels charge the hotels by the following ways: online clicks, being prioritized in the first 1-3 pages, booking volume or turnover. Meanwhile, to fully explain the availability of booking, the time spent on browsing should be taken into consideration.As to the direct channels, the self membership and tourists' evaluation are very important. It is always favorable that permanent credits and positive evaluations are sustained and maintained stably. No one would like his or her credits being cut step by step or cleared off.

\section{The holistic application of online hotel distribution channels}

The application of online hotel distribution channels can be divided into 
business usage and non-business usage, while there are some differences between internet and intranet. As shown in figure 4, there are four different kinds of applications for website usage. Internet

Intranet

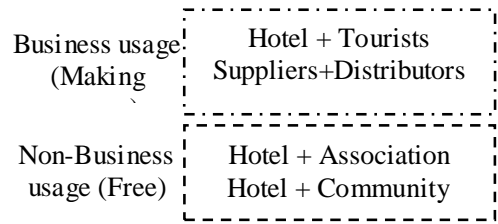

Figure 4 Goals For channel Application

\subsection{Internet and business usage}

If hotel website is used for business usage by the internet, its main purpose is to make money or cut costs for the hotel, low consumption goods suppliers and intermediary distributers. First, the hotel can use many ways to attract tourists, such as :membership, preferential sale, etc.If the tourists want to consult something or complain some service, they can also use the hotel website. Second, the low consumption goods or raw materials suppliers can use hotel website to find its amount of rooms and meeting spaces, and then calculate or forecast its occupancy and the requirements of low consumption goods or raw materials. Third, whether it is an wholesaler or an retailer, the distributor can use hotel website to illustrate its advantages with great ease.

\subsection{Intranet and business usage}

If hotel website is used for business usage by the intranet, its main purpose is to enhance availably internal collaboration of different divisions and harmonize effectively internal management. First, the different divisions, such as:room division, front office, security, etc, can use the intranet to have a online meeting at the beginning of every Monday or in case of emergence. Furthermore, they can jointly recruit, train, select, and evaluate the hotel staff. Second, the intranet can help the managers control and supervise different kinds of problems, such as: arrange the shifts of employee, set up a reminder of special events or VIP (very important person) receptions,prioritize the employee with good appraise, allocate fairly the ibonus or subsidies, etc.

\subsection{Internet and non-business usage}

If hotel website is used for nonbusiness usage by the internet, it will be free or approximately free to all who use them. There are two categories of nonbusiness usage: the hotel website used by its association and the hotel website used by its community. The hotel website used by its association will be not only taken into consideration statistically and academically, but also enhanced by its association by training or mutual intercourse.Meanwhile, the hotel website used by its local community will improve good will, visibility and influence of the community which will in turn bring good and long-term benefits to the hotel. The website will help the community people know what is happening around them.

\subsection{Intranet and non-business usage}

If hotel website is used for nonbusiness usage by the intranet, its main purposes is to achieve the internal resource-sharing and message-sharing. First, the hotel's internal resource can be used for special time,people and event. For example, the hotel can initiate some activities under some adverse circumstances and enlist the volunteers from the employee of different divisions to help or provide the service for the local community or other peoples.Second,the employee can share internal notices, news or announcements by daily access. If some employee have a rest or vacation by coincidence, they can also receive important messages and make some choices or arrangements with great convenience. 
Also, managers can use intranet to solve complaints or conflicts from employee.

\section{Conclusion}

All in all, the contribution of this paper is that, based on the refined type \& operation and application of online hotel distribution channels, combining with practical situations of different hotels, the relevant researchers and managers would be more conscious to find cost-efficient ways and convenient means to enhance service quality, guide the direction of development, or enlarge the profit.

\section{References}

[1] O'Connor,P.,\&Frew,A.J.The future of hotel electronic distribution: expert and industry perspectives, Cornell Hotel and Restaurant Administration Quarterly, vol. 43, pp.33-45, 2002.

[2] Pearce,D.G.,\& Schott,C.Tourism distribution channels:the visitors'perspective,Jour nal of Travel Research,vol.44,pp.50-63, 2005.

[3] O'Connor,P.On-Line pricing: an analysis of hotel-company practices.Cornell Hospitality Quarterly,vol.44, pp. 88-96, 2003.

[4] Choi,S.,\& Kimes,S.E.Electronic distribution channels' effect on hotel revenue management,Cornell Hotel and Restau-rant Administration Quarterly, vol.43, pp. 23-31, 2002.

[5] Carroll,B.,\& Siguaw,J.The evolution of electronic distribution: effects on hotels and intermediaries, Cornell Hotel and Restaurant Administration Quarterly, vol. 44, pp.38-50, 2003.

[6] Schmidt,S.,Cantallops,A.S.,\& Santos,C. P. The characteristics of hotel websites and their implications for website effectiveness,International Journal of Hospitality Management,vol.27,pp.504-516, 2008.

[7] Noone,B.M.,\& Mattila,A.S.Hotel revenue management and the internet: The effect of price presentation strategies on customers' willingness to book, Interna-tional Journal of Hospitality Management, vol.28 , pp.272279, 2009.
[8] Morosan,C.,\& Jeong,M.Users'perceptions of two types of hotel reservation web sites, International Journal of Hospitality Management, vol.27, pp. 284-292, 2008.

[9] Rong,J.,Li,G.,\& Law,R.A contrast analy -sis of online hotel web service purchasers and browsers.International Journal of Hospitality Management, vol.28, pp.466478, 2009.

[10] Sparks,B.A.,\& Browning,V. The impact of online reviews on hotel booking inten-tions and perception of trust. Tourism Management,vol.32,pp.1310-13 23, 2011.

[11] Kotler,P.,\& Armstrong,G.Principles of marketing(14th).Upper Saddle River, NJ: Pearson Prentice Hall. 2012.

[12] Walker,J.R.,\& Walker,J.T.Tourism concepts and practices.Upper Saddle River, NJ:Pearson Prentice hall. 2011.

[13] Vallen,G.K.,\& Vallen,J.J.Check-in check out:managing hotel operations(8th).Upper Saddle River,NJ:Pearson Prentice Hall. 2009.

[14] Amadeus Hotel IT.Amadeus Hotel Plat form.http://www.amadeus.com/hotelit/ho tel -platform. html. 2012-05-16/2012-7-22.

[15] Ctrip.com International,Ltd.Ctrip home page--Navigate China with the best. http: //english.ctrip.com/.2012-05-8/2012-7-25.

[16] 2012 Hilton Worldwide. A Legacy of Innovation.http://www3.hilton.com/en/ about/index.html. 2012-05-20/2012-7-28.

[17] Hostelworld.com Limited.About hostel world.com--Our Mission.http://www.hos tel world.com/aboutus.php.2012-05-22/20 127-29.

[18] Murphy,J., Forrest,E.J.,Wotring, C.E.,etc. Hotel management and marketing on the internet: An analysis of sites and features, Cornell Hotel and Restaurant Administration Quarterly, vol.37, pp. 70-82, 1996.

[19] Lim,W.M.,\& Hall,M.J.Pricing consisten -cy across direct and indirect distribution channels in South West UK hotels, Journal of Vacation Marketing, vol.14, pp. 331-344, 2008.

[20] Tanford,S.,Baloglu,S.,\& Erdem,M.Travel packaging on the internet: the impact of pricing information and perceived value on consumer choice, Journal of Travel Research,vol.51, pp.68-80, 2012.

Jinhoo Kim,David C.Bojanic,Rodney B.Warnick.Price bundling and travel product pricing practices used by online channels of distribution, Journal of Travel Research, vol.47,pp.403-412, 2009. 